\title{
芳香族アミド類の特性を活かしたらせんフォルダマーの創製
}

\author{
棚 谷 綾
}

\section{Novel Helical Foldamers Based on the Conformational Properties of Aromatic Amides}

\author{
Aya Tanatani \\ Department of Chemistry, Faculty of Science, Ochanomizu University; \\ 2-1-1 Otsuka, Bunkyo-ku, Tokyo 112-8610, Japan.
}

(Received August 20, 2018)

\begin{abstract}
In this review, we focus on our recent work on the development of novel helical foldamers based on the cis conformational properties of aromatic amide bonds. First, we describe the conformational properties of $N$-alkylated pyrroleamides and their oligomers. The conformation of the amide bond on the pyrrole ring is altered by $N$-alkylation, and the ratio of the cis conformer is lower in $N$-methylated amides with an $N$-pyrrole ring compared with that in $N$-methylbenzanilide. Pyrrole-containing oligomers, in which benzene and pyrrole rings are linked alternately by amide bonds with chiral $N$-substituents, show significant $\mathrm{CD}$ signals that depend on the chain length, temperature, and solvent properties, indicating that the oligoamides take folded conformations in solvents. Second, we describe the design and synthesis of alternately $N$-alkylated aromatic oligoamides as novel helical oligoamides with larger cavities compared with those of poly ( $N$-alkylated $p$-benzamides). Spectroscopic studies and calculated optimized structures indicate that these oligoamides adopt helical structures with a cavity of about $9 \AA$ in diameter. Finally, we describe the synthesis of a series of strained aromatic oligoamide macrocycles based on the cis conformational preference of the aromatic $N$ alkylated amide bond, building on the work of Huc et al. on the construction of large macrocycles by cyclization of helical quinoline oligoamides. The crystal structures are also presented. Our findings demonstrate that $N$-alkylated amides with the cis conformation are useful building blocks for unique aromatic foldamers.
\end{abstract}

Key words_— foldamer; aromatic amide; conformation; cis conformer

\section{はじめに}

フォルダマー（foldamer）という用語は， 1998

年に Gellman によって定義されたものであるが, ${ }^{1)}$ その源流となる研究は, 生化学, 分子認識, 超分子 化学を含め, 何十年にもわたって行われてきた. 有 機化学研究者は, 生体高分子であるタンパク質, 核 酸, 多糖類などの, 美しく秩序だった構造とそれに 基づく機能に魅了され，これらの生体高分子を模倣 した分子を構築する試みがなされてきた。 そして, 生体高分子とは全く異なる，種々の人工的な骨格を 持つ分子が，分子間及び分子内相互作用によって, 生体高分子同様の折りたたみ構造を形成することが 報告されてきた。当初，これらの分子は，folding

お茶の水女子大学基幹研究院自然科学系（ (112-8610 東京都文京区大塚 2-1-1)

e-mail: tanatani.aya @ocha.ac.jp

本総説は, 日本薬学会第 138 年会シンポジウム S09 で

発表した内容を中心に記述したものである. oligomer などと呼ばれていたが, ${ }^{2)}$ Gellman によつ てフォルダマー (foldamer) と名付けられた. ${ }^{1)}$

Gellman による定義では，フォルダマーとは「制 御された特定の立体構造を形成する高分子の総称」 とされていて，いたって漠然としたものであった. その後, Mooreらは, 2001 年の総説によって, フォルダマーをより厳密に定義することを提案し

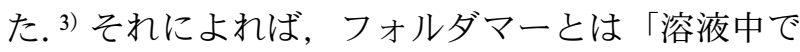
秩序だつた構造を持つオリゴマーで, その構造が隣 接していない単位構造間における非共有結合性相互 作用の集積によって安定化されているもの」とされ た。さらに, Mooreらは,「folding」という言葉が ランダムな構造から秩序だつた折りたたみ構造への 動的な変換を意味することに着目し，フォルダマー とは「ランダムな状態と秩序だった構造との間の動 的な変換が可能であるもの」という制限も付してい る. Gellman と Moore がフォルダマーの定義につ いての論文を出したことにより，フォルダマーとい 


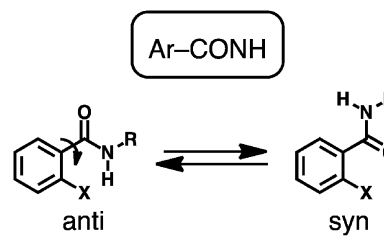

anti preferred

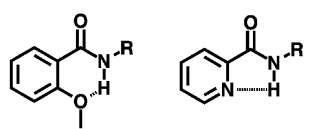

syn preferred
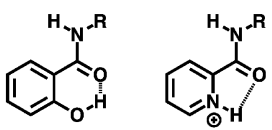
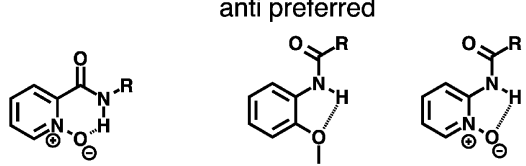

syn preferred

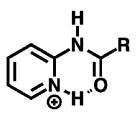

Fig. 1. Control of Conformation of Aromatic Amides Based on Electronic Effects

う言葉は市民権を得て，1つの研究分野として定着 し，定期的に学会4)も開催されるに至った。

2011 年には, Guichard と Hucによって「Synthetic foldamers」という総説がだされた. ${ }^{5)}$ 彼らは 自然界がたつた 20 種類のアミノ酸から高機能を持 つタンパク質を生み出したこと，しかしながら，進 化の過程ならではの制約も受けてきたのに対して, われわれ化学者は，それとは無関係に，膨大な数の 化合物を扱うことができることから，人工フォルダ マーの可能性が無限に満ちていることを述べている.

筆者らは，芳香族アミドやウレアなどの構造化学 的研究の過程で，その立体特性をらせんフォルダ マーの創製へと展開してきた，本稿では，らせん才 リゴアミドに関する筆者らの最近の研究について紹 介する.

\section{アミド結合の立体特性}

筆者らは芳香族アミドの特性に着目して新たな フォルダマーの創製研究を行ってきた. 2004 年に 発表された Huc の総説「Aromatic Oligoamide Foldamers」には，芳香族アミドユニットは 2 次構造 を予測，設計することが可能で，構造の微調整も簡 便であること，また，合成のし易さ，化合物の安定 性といつた観点から，フォルダマーの構成要素とし

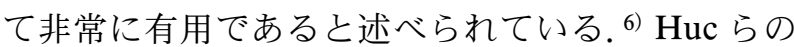
キノリンオリゴアミド研究に代表されるように，ア ミド結合を用いた様々なフォルダマーが創製されて きた. ${ }^{7)}$ 一般に，アミド結合は，C-N 結合の部分二 重結合性から平面性を持ち，堅固性と柔軟性を併せ
持つた結合である．また，水素結合のドナー及びア クセプターとして機能することから，これらの電子 的な相互作用を活かした機能性分子の構築に応用さ れてきた。例えば，Hucらの芳香族オリゴアミド においては，アミド結合と芳香環（ときにはピリジ ン環などの複素環）のオルト位官能基（ピリジン環 の場合は窒素原子）との間の相互作用によるアミド 結合と芳香環との間の立体制御が折りたたみ構造の 鍵となっている (Fig. 1).

一方，筆者らがフォルダマー創製の基盤としてい るのは，芳香族アミドの立体特性にある．筆者が所 属していた東京大学薬学部（首藤紘一・現 名誉教 授，影近弘之・現 東京医科歯科大学教授ら)では, 合成レチノイド（ビタミンA）の医薬化学研究の 過程で，ベンズアニリド等の芳香族二級アミドが結 晶中及び各種溶液中において trans 型で存在してい るのに対して， $N$-メチル化（一般的には $N$-アルキ ル化）した三級アミドが結晶中で cis 型をとり，溶 液中でも cis 型を優先することを見い出した（Fig. 2). 8 ,9) 筆者は， $N$-アルキル化に基づく cis 型構造優

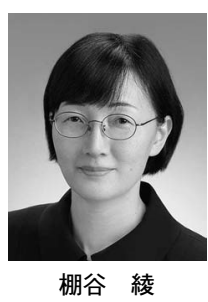

1998 年東京大学大学院薬学系研究科博 士課程 (首藤紘一・現名誉教授) 修了, 米国イリノイ大学アーバナシャンペー ン校化学科博士研究員 (Jeffrey S. Moore 教授), 神奈川大学工学部博士 研究員 (横澤 勉教授), 東京大学分子 細胞生物学研究所助手 (橋本祐一教授) を経てお茶の水女子大学基幹研究院准 教授. 専門は有機構造化学, 医薬化学. 


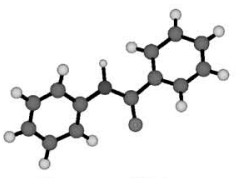

Benzanilide (crystal structure)

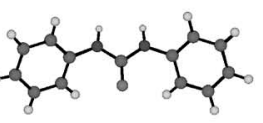

$N, N$-Diphenylurea (crystal structure)
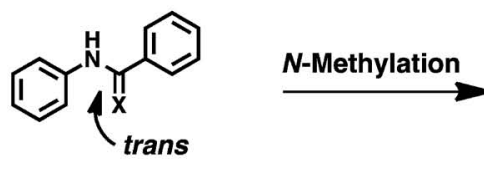

$\mathrm{X}=0$

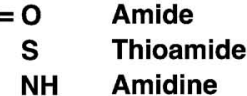

$\mathrm{NH}_{2}{ }^{+}$Amidinium ion

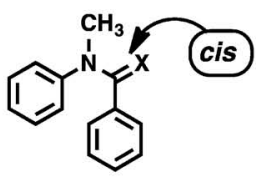

\section{$\mathrm{N}$-Methylbenzanilide \\ (crystal structure)}
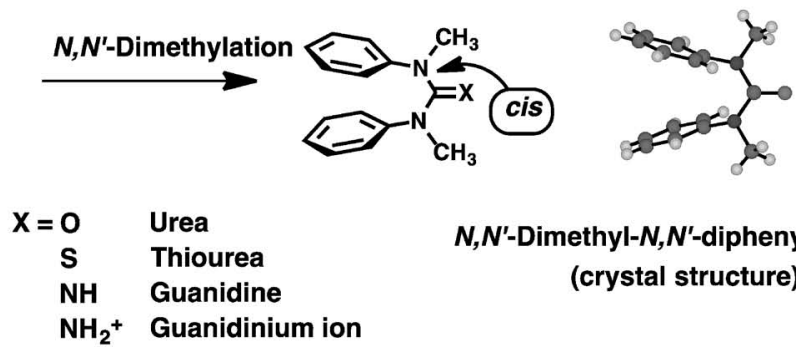

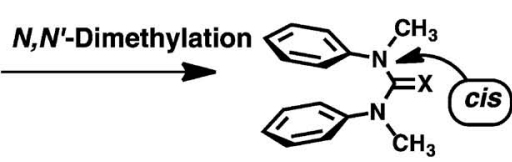

$N, N$ '-Dimethyl- $N, N^{\prime}$-diphenylurea

(crystal structure)

Fig. 2. Cis Conformational Preference of Aromatic N-Methylated Amides and Related Functional Groups

先性が，芳香族アミドだけでなく，ウレアやグアニ ジンなどにおいてもみられること（Fig. 2),10)ま た，複数のベンゼン環を cis 型ウレア若しくはグア ニジンで連結すると芳香環が層状に積み重なつた構 造を構築することができ，このときメ夕位で連結し た場合にはすべてに軸不斉がそろった，らせん構造 をとることを示した. ${ }^{11,12)}$

cis 型構造をとる $N$-メチルベンズアニリドの場合 は，2つの芳香環の二面角が約 $60^{\circ}$ 程度で向かい 合っている。このような分子形状は folding 構造の 部分構造として有用であり，また同様の立体構造は cis 型オレフィン又は環構造などをリンカーとする ことで構築できるものの，アミド結合の場合は，そ の結合の柔軟性からユニークな動的挙動を発揮する 分子の創製に展開し得ると考えられる. ${ }^{13)}$

$N$-アルキル-p-ベンズアミドポリマーのらせん構 造

筆者らが芳香族 $N$-メチル化アミドの立体特性を 基にした構造化学研究を展開していた頃, 横澤 勉 教授 (神奈川大学工学部) らは, 分子量分布が狭く, 望みの鎖長を持つ $N$-アルキル- $p$-ベンズアミドポリ マーを合成する連鎖重縮合の手法を見い出してい た. ${ }^{14)}$ 筆者は横澤教授の下で研究する機会を得て,

$N$-アルキル-p-ベンズアミドポリマーのらせん形成 について検討した．アミド結合の窒素原子上に光学 活性な置換基を導入したポリマーを, Fig. 3 に示し た連鎖重縮合反応により合成した。このとき，開始

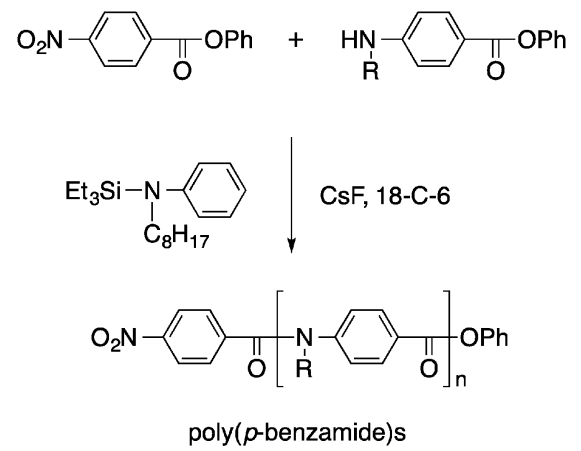

$\mathrm{R}=\mathrm{NY}^{\mathrm{O}} \sim_{\mathrm{O}} \sim \mathrm{O}$

Fig. 3. Chain-growth Polycondensation to Obtain Poly ( $p$ benzamide) s Bearing Chiral $\mathrm{N}$-Substituent

剂（phenyl $p$-nitrobenzoate） とモノマー分子 (phenyl $p$-alkylaminobenzoate) の比率を変えて連 鎖重縮合を行うことで，様々な分子量を持ち，分子 量分布の狭いポリアミドを合成し，その鎖長及び温 度依存的 CD スペクトルの解析により，動的らせん 分子としての挙動を示すことを明らかとした。 また, $\mathrm{CD}$ スペクトルの理論的解析 ${ }^{15)}$ により Fig. 3 に示し た光学活性側鎖を持つポリアミドが右巻きらせんで あることを同定することに成功した. ${ }^{16)}$ 当時として は，人工フォルダマーのらせんの立体構造を明確に 証明できた稀な例であった。

$N$-アルキル複素芳香族オリゴアミド

$N$-アルキル化に基づく芳香族アミドの cis 型構造 

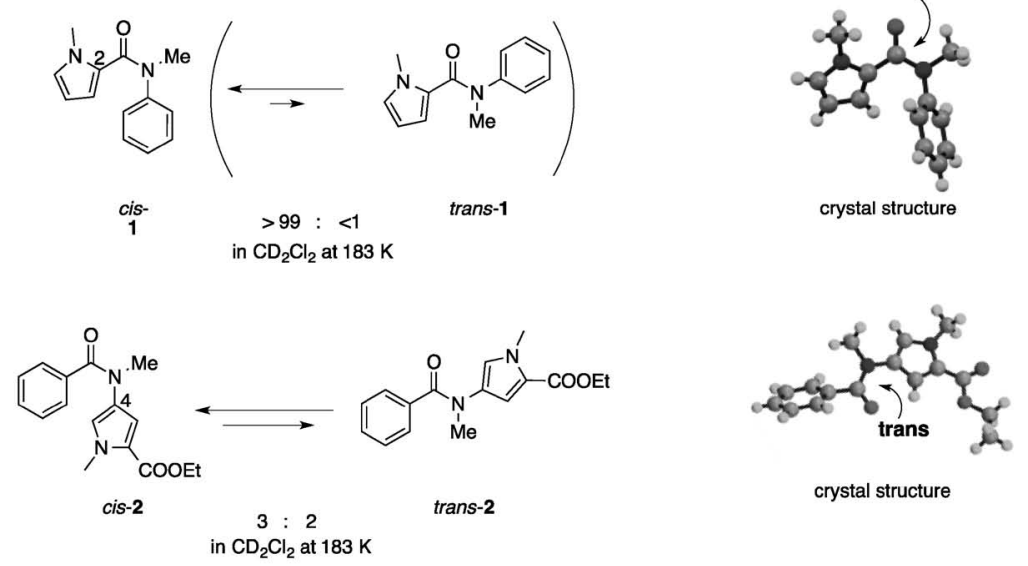

crystal structure

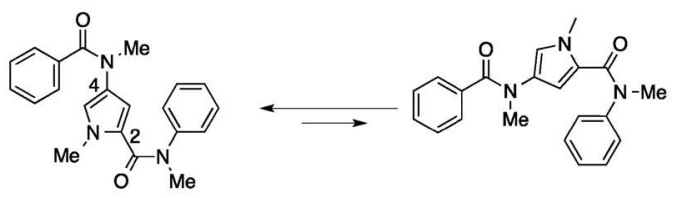

(cis, cis)-3 $4: 1$
in $\mathrm{CD}_{2} \mathrm{Cl}_{2}$ at $208 \mathrm{~K}$

(trans, cis)-3

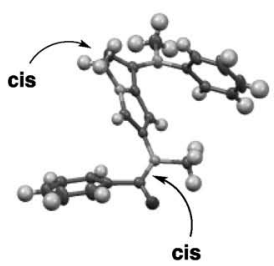

crystal structure

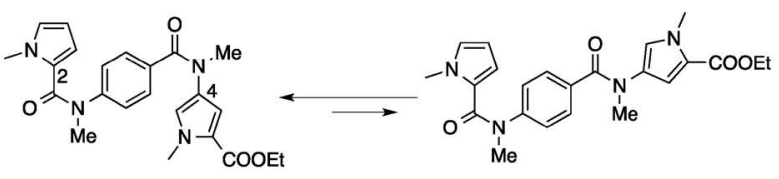

(cis, cis)-4

$7: 3$ in $\mathrm{CD}_{2} \mathrm{Cl}_{2}$ at $233 \mathrm{~K}$

(cis, trans)-4

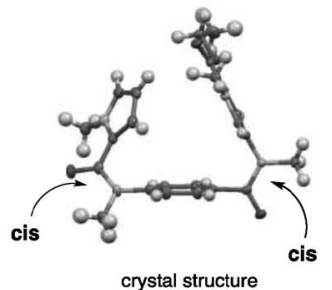

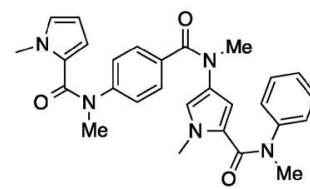

(cis, cis, cis)-5

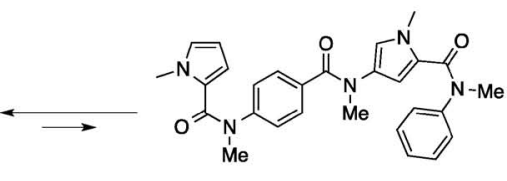

(cis, trans, cis)-5

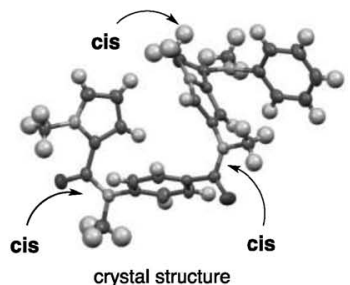

Fig. 4. Conformational Equilibrium and Crystal Structures of Pyrrole-containing N-Methylated Amides

優先性に関する研究は, これまで主にベンゼンやナ フタレンなどの炭化水素系芳香族分子を中心に行わ れてきた. 岡本 巌教授（昭和薬科大学）らは，ピ リジン環を持つオリゴアミドが，酸の添加によって 様々な立体構造を形成することを報告している. ${ }^{17)}$ 一方，5 員環の複素芳香環を持つオリゴアミドの立 体構造に関する知見はほとんど報告されていなかつ た．そこでピロール環を導入したオリゴアミドの立 体構造を解析することとした，オリゴマーの合成に 先立って, $N$-メチルベンズアニリドの一方のベン ゼン環をピロール環に変えたアミド化合物の立体構 造を解析した (Fig. 4). ${ }^{18)}$ その結果, カルボニル側
のベンゼン環を $N$-メチルピロールに変えた化合物 1 は $N$-メチルベンズアニリド同様, cis 型構造で存 在していたのに対して，窒素原子上のベンゼン環を ピロール環に変えた化合物 $\mathbf{2}$ では cis 型を優先する ものの，その割合が減少することがわかつた。同様 の傾向は，ピロール環を導入したジアミド体 $\mathbf{3}, 4$ やトリアミド体でもみられる。 これらの化合物で は，アミド結合に関して複数の幾何異性体が考えら れるが， ${ }^{1} \mathrm{H}$ NMR では 2 種類のコンフォマーしか 観測されず，いずれもメジャーコンフォマーはアミ ド結合が cis 型となったものであり，マイナーコン フォマーは窒素原子上にピロール環を持つアミド結 

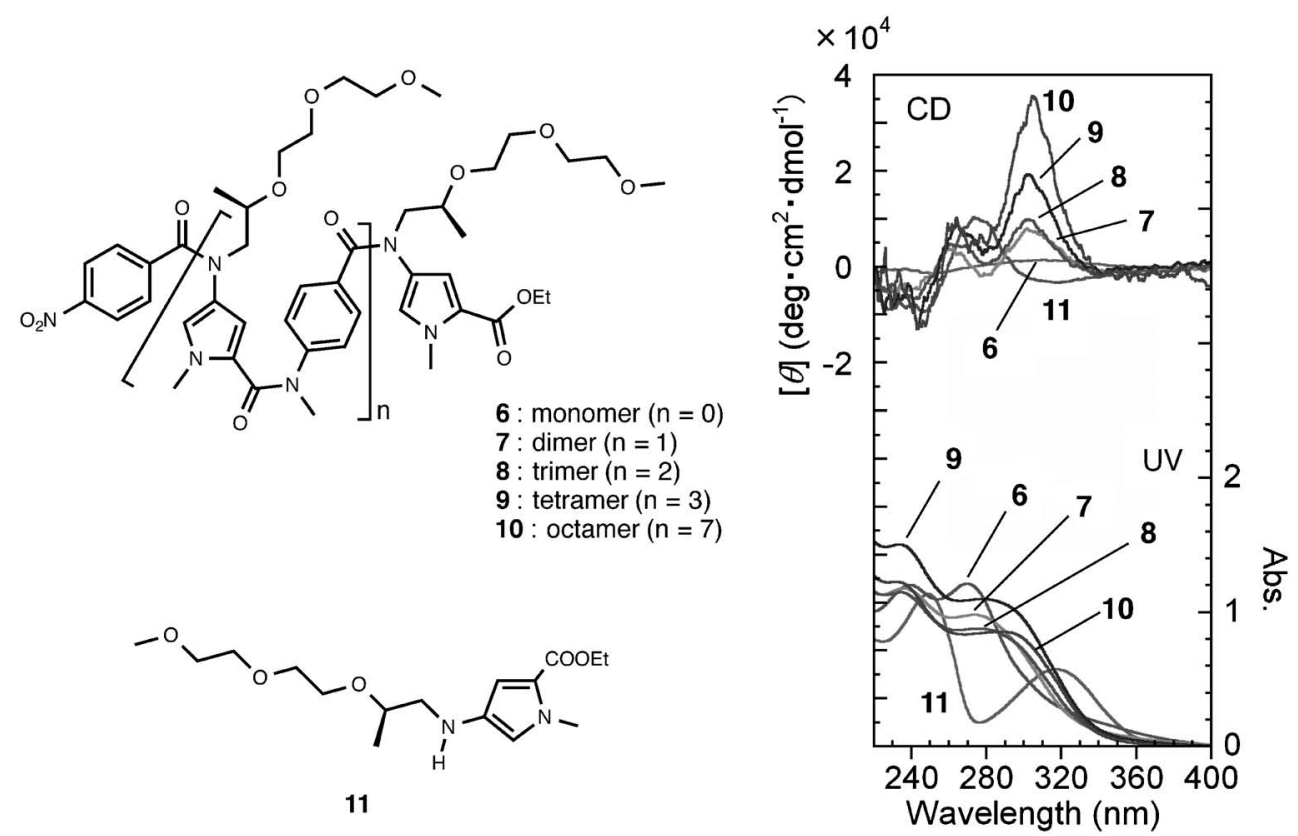

Fig. 5. Structures and CD Spectra of Pyrrole-containing Oligoamides

合だけが trans 型となったコンフォマーであった. $N$-メチルアセトアニリドでは $N$-メチル基の存在に より $N$-フェニル基がアミド平面からねじれること が cis 型優先性の要因とも考えられており, ${ }^{19)}$ より 立体障害の少ないピロール環に変えることにより, その効果が減少しているためとも考えられる。一方 で，マイナーコンフォマーの割合は，モノマー，ダ イマー, トリマーと分子が大きくなるにつれて小さ くなることから，ピロール含有アミドの場合もオリ ゴマーとなることで, 秩序だった折りたたみ構造を 形成すると考え, 光学活性側鎖を導入したピロール 含有オリゴアミド 6-10を合成した（Fig. 5)。オリ ゴアミド 6-10 は同じ光学活性な置換基を持つアミ ン 11 と異なり, CD 吸収を持ち，モノマーを除く710 では $300 \mathrm{~nm}$ 付近に鎖長に比例して増加する強い 正の CD 吸収を持つことから，ピロール含有オリゴ アミドが秩序だった折りたたみ構造をとることが示 された．ピロール含有オリゴアミドの場合，溶媒に よって CD 強度が大きく異なり，特に，低極性溶媒 中では動的な折りたた夕構造をとるのに対して，水 溶液中では折りたたみ構造が不安定化されていると 考えられ, $N$-アルキル- $p$-ベンズアミドポリマーの場 合とは異なる性質を持つことも明らかとなつた。 ${ }^{20)}$

内部空間を拡張した芳香族オリゴアミド

らせんフォルダマーの中には，表面若しくは内部
空間において特異的な分子と相互作用するものが種 々知られており，光学活性な分子と相互作用する場 合には，らせんの巻きが一方向に偏る場合がある. 特に，らせんの内部空間においては，そのサイズや 分子形状によって特異的な分子を取り込むことが可 能であり，特徵的な分子認識能や不斉識別能などの 性質を持たせることができる. ${ }^{21,22)}$

先に示した $N$-アルキル- $p$-ベンズアミドポリマー （Fig. 3）のらせん構造は，モノマー分子が 3 つで 一巻きした構造を持ち, その内部空間は分子を取り 込むには小さい. ${ }^{16)}$ そこで，より内部空間の大きな アミドオリゴマーの創製を試みた，分子設計におい ては，芳香族アミドの立体特性を基に， $p$-ベンズア ミドオリゴマーに対して 1 つおきのアミド結合に $N$-アルキル基を導入することで，交互にトランス 型アミドとシス型アミドを持つオリゴマーとなり, より大きな内部空間を持つらせん分子ができると予 想した (Fig. 6). ${ }^{23)}$

$N$-メチル基を交互に持つモノマー分子 12a は, 溶液中では，溶媒によらず，予想したように二級ア ミドが trans 型，三級アミドが cis 型で存在してい た. $\mathrm{CD}_{2} \mathrm{Cl}_{2}$ 中の温度可変 $\mathrm{NMR}$ の測定により, $233 \mathrm{~K}$ でマイナーピークが観測され，ケミカルシフトの比 較から，ニトロフェニル基側の三級アミドが trans 型となった（trans, trans, cis） 型であることがわ 
<smiles>CN(C)c1ccc(C(=O)N(C)c2ccc(N(C)C)cc2)cc1</smiles>

$N$-methyl-p-benzamide oligomers

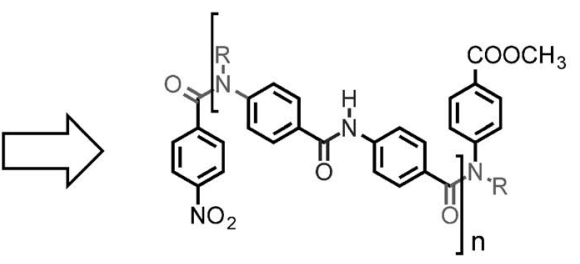

Alternately $N$-atkylated $p$-benzamide oligomers $12(n=1), 13(n=3), 14(n=5)$, and $15(n=7)$

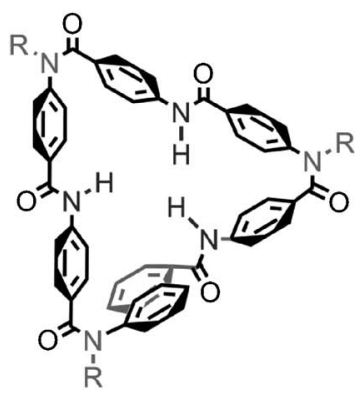

$$
\begin{aligned}
& \text { a: } \mathrm{R}=\mathrm{CH}_{3} \\
& \text { b: } \mathrm{R}=n-\mathrm{C}_{3} \mathrm{H}_{7} \\
& \text { c: } \mathrm{R}=n-\mathrm{C}_{8} \mathrm{H}_{17} \\
& \text { d: } \mathrm{R}=
\end{aligned}
$$

Fig. 6. Structures of $N$-Methyl- $p$-benzamide Oligomers and Alternately $N$-Alkylated $p$-Benzamide Oligomers

かつた. 一方，12a の結晶構造を解析したところ， 再結晶溶媒によって擬似結晶多形が得られ，それぞ れ結晶中で異なる立体構造をとつていた。 クロロべ ンゼン/ヘキサンから得られた結晶では，溶液中と 同じ（cis, trans, cis）型構造で存在していたが，塩 化メチレン/ヘキサンから得られた結晶では, $\mathrm{CD}_{2} \mathrm{Cl}_{2}$ 中でマイナーコンフォマーであった（trans, trans, cis）型で，また，DMSO- $d_{6}$ から得られた結晶で は，すべてのアミド結合が trans 型の構造であっ た.この要因は，溶媒の極性や結晶中の分子間相互 作用などの影響が関与していると考えている。一 方，窒素原子上の置換基を $n$-プロピル基にしたモ ノマー分子 12bでは, 2 種類の溶媒 (クロロホルム/ ヘキサン及び DMSO- $d_{6}$ ) から得られた結晶がいず れも予想した (cis, trans, cis) 型構造をとっており, 窒素原子上の置換基をかさ高くすることで，溶媒や 分子間相互作用などの影響を受け難くなり，アミド の立体特性に基づいた立体構造をとり易くなつてい ることが示唆された.

オリゴマーの溶解性も考慮し，窒素原子上の置換 基として $n$-オクチル基（Fig. 6, c シリーズ）及び 光学活性な置換基（ $\mathrm{d}$ シリーズ）を合成し，その $\mathrm{UV} / \mathrm{CD}$ スペクトルを解析した。 クロロホルム中の CD スペクトルでは，オリゴマーの鎖長が長くなる につれて，CD シグナルの長波長シフトを伴って， 強度が増し，特に，ペンタマー14d で著しい増加 が観測された [Fig. 7(a)]。DMSO 中のCD スペク (a)

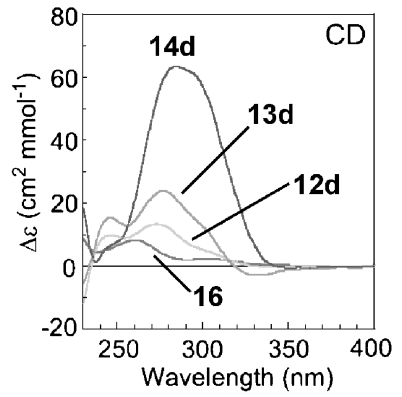

(b)

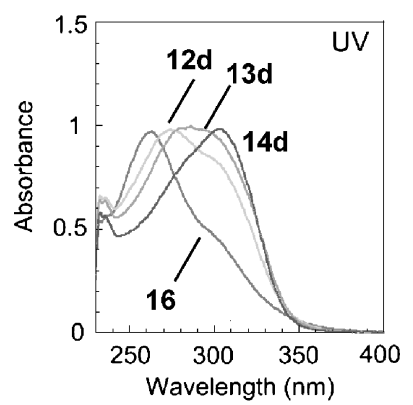

Fig. 7. (a) CD and (b) UV Spectra of Alternately $N$-Alkylated $p$-Benzamide Oligomers 12d, 13d, and 14d

The spectra of methyl 4-(4-nitrobenzoylamino) benzoate with a chiral $\mathrm{N}$-substituent (16) is shown for comparison.

トルにおいても同様の傾向を示したが，クロロホル ム中ほど，ペンタマー 14d における著しい増加は みられなかった。一方，UV スペクトルは，鎖長が 長くなるにつれて吸収極大が長波長シフトした [Fig. 7 (b)]．同様にn-オクチル基を持つオリゴ マーでもペンタマー $\mathbf{1 4 c}$ までは長波長シフトがみら れたが，ヘキサマー 15c ではそれ以上の長波長シフ 


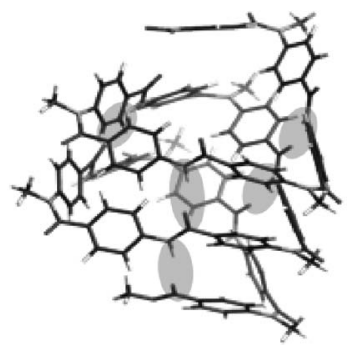

side view

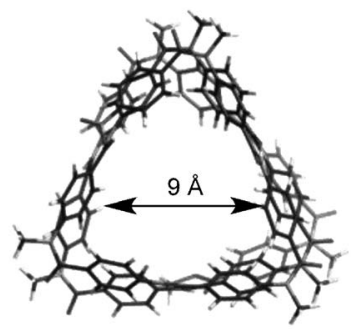

top view
Fig. 8. Calculated Structures of Alternately $N$-Methylated $p$ Benzamide Pentamer 15a

Intramolecular hydrogen bonds are shown by gray circles.

トは起こらなかった。このような鎖長依存的な長波 長シフトは $N$-アルキル-p-ベンズアミドのオリゴ マーでは観測されず，本オリゴマーに特徽的な性質 である.

$\mathrm{CD}$ スペクトルの鎖長及び温度依存性から，交互 にN-アルキル化したオリゴアミドがらせん構造を 形成していることが示唆されたが，オリゴマーの結 晶構造を得ることができなかったため, 計算化学に より安定構造を算出した。モノマー 12aの（cis, trans, cis）型の結晶構造を基に，ペンタマー 15a の構造最適化をした結果，オリゴマーがらせん構造 を形成し，その際，二級アミド結合がらせんの上下 で水素結合している構造が得られた（Fig. 8)。 せんを巻くにつれて，二級アミド結合の分子内水素 結合により，ベンゼン環同士が近接することとな り，その芳香環一芳香環相互作用の結果，UV スペ クトルの長波長シフトが起こったと考えられる。し たがって，交互に $N$-アルキル化したオリゴアミド はすべて $N$-アルキル化したアミドオリゴマーと比 ベてより剛直ならせん構造をとつていると考えられ る。計算により得られた結晶構造では，らせんの内 径は直径が約 $9 \AA$ と，分子を取り込むには十分な 大きさを有していた，現在，本オリゴマーの内部空 間での分子認識能や不斉誘導等を詳細に検討してい る.

\section{大環状キノリンアミドオリゴマーの合成}

最後に，芳香族三級アミドの cis 型優先性を新た な環状化合物の合成に応用した例を紹介する，上述 したように，Hucらは，キノリンの 2, 8 位を二級 アミド結合で連結したオリゴマー [Fig. 9(a)] が 安定ならせん構造を形成することを見い出し, 種々 のユニークな構造や機能を持つらせん分子を構築し (a)

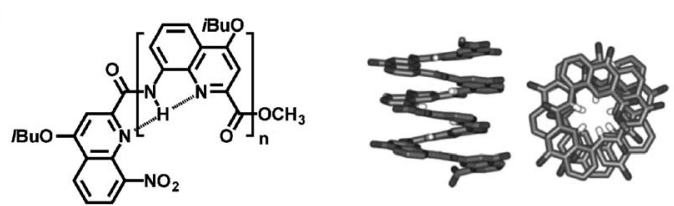

(b)

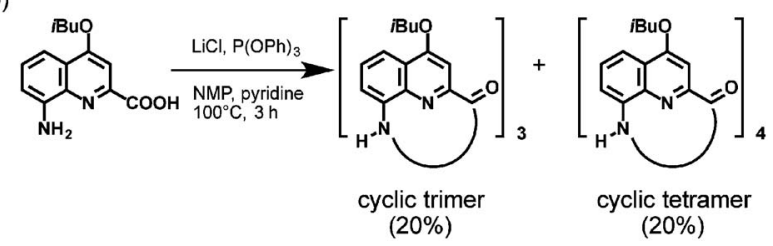

Fig. 9. (a) Structure and Conformation of Quinoline Oligoamides, and (b) Isolation of Cyclic Oligomers as Byproducts of Polymerization

(a)

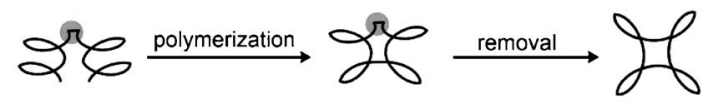

(b)

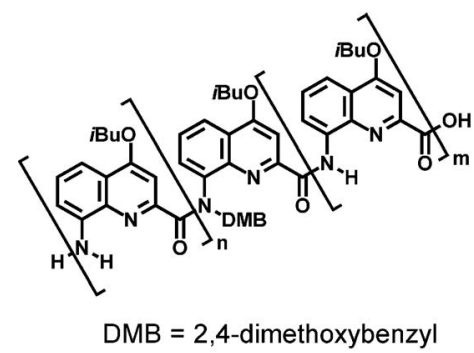

Fig. 10. (a) Schematic Illustration of Synthesis of Cyclized Oligomers, and (b) Structures of Designed Precursors

てきた. ${ }^{7)}$ Huc らは，8-アミノキノリン-2-カルボン 酸誘導体からオリゴマー，ポリマーを合成する反応 で，副生成物として環状トリマーや環状テトラマー が得られることを見い出した $[\mathrm{Fig} .9(\mathrm{~b})] .{ }^{24)} し か$ しながら，より大きな環構造を持つ環状オリゴマー は，本反応においても，また，二級アミドからなる オリゴマーの縮合反応においても得ることはできな かった.

筆者らは，Huc らとの共同研究により，環化前 駆体であるオリゴマーの適当な位置に折れ曲がった cis 型アミド結合を導入することで，両端のアミノ 基とカルボキシル基が近接し，環化反応が進行し易 くなると考え，環状オリゴアミドの合成を試みた [Fig. 10(a) ]. ${ }^{25)}$ アミド結合窒素原子上に導入する 置換基としては，最終的に，すべて二級アミドの環 状オリゴアミドへと導くために，容易に除去可能な 2,4-dimethoxybenzyl（DMB）基を選択した［Fig. 

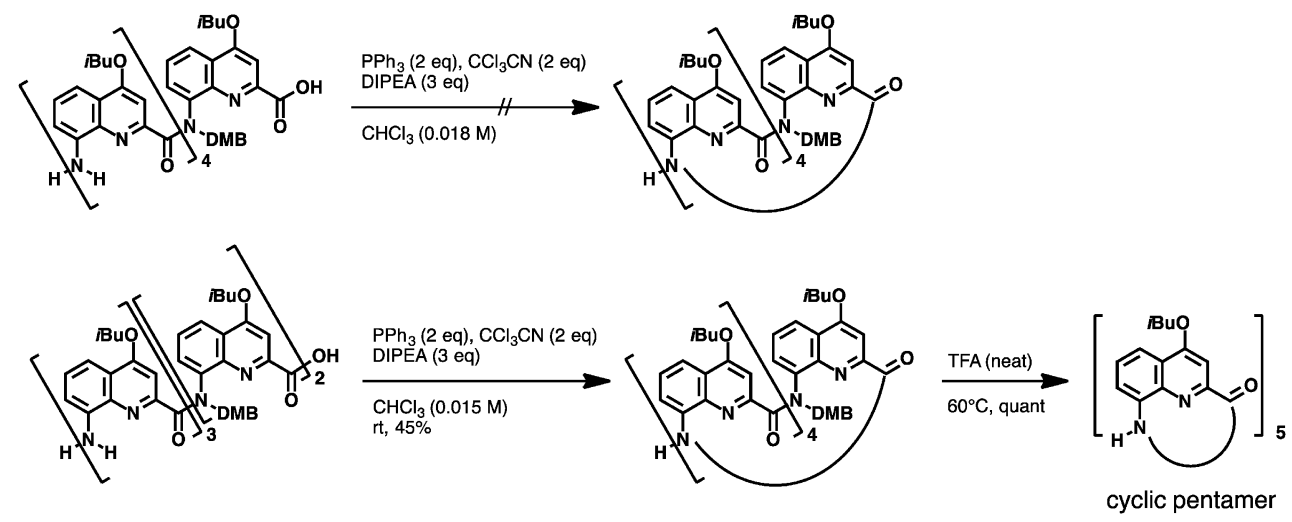

Fig. 11. Synthetic Schemes of Cyclic Pentamer

10 (b)].

まず，末端にアミノ基とカルボキシル基を持つキ ノリンアミドペンタマーのカルボキシル基側のアミ ド結合に DMB 基を導入した化合物の環化反応を 行つたが，目的の環化体は得られなかった（Fig. 11)。ついで，2つのアミド結合に DMB 基を導入 したペンタマーを用いて同じ条件で反応を行ったと ころ，目的とする環化体が収率 $45 \%$ で得られた。 両環化前駆体の合成中間体（保護基のついたペンタ マー）の結晶構造の比較から，DMB 基を 1 つ導入 したペンタマーでは両末端が離れた構造をとってい るのに対して，DMB 基を 2 つ導入したペンタマー では同一方向に位置していることから, 折れ曲がり 構造の違いが反応性の差に反映されたと考えてい る. 環化体の DMB 基を除去することで，すべて二 級アミドの環状ペンタマーを得ることができた。

環状ペンタマーの ${ }^{1} \mathrm{H}$ NMR スペクトルは室温で は激しくブロードしており, $\mathrm{CDCl}_{3}$ 中， $273 \mathrm{~K}$ 以下 でシャープなシグナルとなり，5つの芳香環及びア ミドプロトンがすべて非等価に観測された。環状ぺ ンタマーの結晶構造では，5つの二級アミド結合の うち，1つのアミド結合が cis 型構造をとり，全体 として 8 の字型のキラルな構造をとつていた（Fig. 12). 興味深いことに, 環構造の中で, 同じ巻き方 向の 2 つの短いらせん構造が存在しており, キラル な構造となっていた。 らせん構造は, 環状トリマー や環状テトラマーのような小さい環構造では見るこ とができない. 今後, 同様の手法で, より大きな環 構造を持つオリゴアミドを合成し，環状のらせん分 子の構造特性や機能を明らかにしていきたいと考え ている.

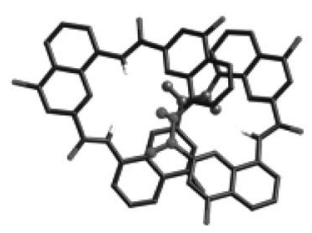

top view

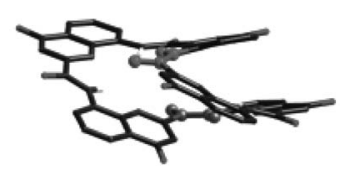

side view
Fig. 12. Crystal Structure of Cyclic Pentamer

おわりに

以上のように，本稿では芳香族アミドの立体特性 を活かした，らせん状及び環状フォルダマーの創製 に関する研究を紹介した。 $N$-アルキル化芳香族ア ミドの cis 型優先性は一般性を持った性質であり, また，ユニークな構造を持つフォルダマーの骨格と しても，またフォルダマー構築の部品としても有用 であると言える.

フォルダマーに関する研究は, Moore らの総説 でも述べられているように，「フォルダマー構造を とる新規なオリゴマーの創製研究」と「フォルダマー 構造をとることによつて機能を持つ分子の研究」に 分類できる，フォルダマー分子の機能化は，情報メ モリ，遺伝子治療のためのデリバリーなど，多岐に わたる。しかしながら，現実問題として，機能化の ために，どのように精密に分子設計し，合成できた としても，目論んだ機能と，実際に合成した分子が 持つ機能とは隔たりがあることが多い。そうはいつ ても，自然界が進化の過程で，低分子から始まりさ らに様々なマクロな構造体においても「folding す る」ことで機能を持たせるに至った事実以上に, フォルダマーの持つ構造的な美しさには強く魅かれ るものがあり，それが研究を続けていく要因となつ 
ていることは否めない.

謝辞筆者らの芳香族アミドの研究は, 東京大 学・首藤紘一名誉教授, 東京医科歯科大学・影近弘 之教授の指導の下開始し, 多くの研究は, 東邦大学 薬学部東屋 功教授, 千葉大学・桝飛雄真准教授と の共同研究として行われたものである. また，博士 研究員としてフォルダマー研究に携わるきっかけを 頂いた米国 Illinois 大学 Urbana-Champaign 校 · Jeffrey S. Moore 教授, 神奈川大学・横澤 勉教授 並びに，フォルダマーに関する共同研究により多く の学生派遣を受け入れて頂いた Bordeaux 大学・ Ivan Huc 教授 (現 - Ludwig-Maximilians 大学 München 校）に感謝いたします。本稿で紹介した 研究は工藤まゆみ博士（現・群馬工業高等専門学 校, オリゴウレア), 東條有希子修士（ピロールア ミド)，漆原 紅博士（交互アルキル化アミド，大 環状オリゴアミド）を始めとする研究室に在籍した 大学院生, 学部学生の努力の賜であり, 心より感謝 いたします。なお，本研究は，科学技術振興機構さ きがけ研究, 日本学術振興会科研費, 三菱化学研究 奨励基金，旭硝子財団研究助成，住友財団基礎科学 研究助成の支援の下で行われたものであり，ここに 深く感謝いたします。

利益相反＼cjkstart開示すべき利益相反はない.

\section{REFERENCES}

1) Gellman S. H., Acc. Chem. Res., 31, 173-180 (1998).

2) Chem. Eng. News, 77 (30), 41-44 (1999).

3) Hill D. J., Mio M. J., Prince R. B., Hughes T. S., Moore J. S., Chem. Rev., 101, 3893-4012 (2001).

4) Tomasini C., Huc I., Aitken D. J., Fülöp F., Eur. J. Org. Chem., 3408-3409 (2013).

5) Guichard G., Huc I., Chem. Commun., 47, 5933-5941 (2011).

6) Huc I., Eur. J. Org. Chem., 17-29 (2004).

7) Jiang H., Léger J.-M., Huc I., J. Am. Chem. Soc., 125, 3448-3449 (2003).

8) Kagechika H., Himi T., Kawachi E., Hashimoto Y., Shudo K., J. Med. Chem., 32, 2292-2296 (1989).

9) Itai A., Toriumi Y., Saito S., Kagechika H.,
Shudo K., J. Am. Chem. Soc., 114, 1064910650 (1992).

10) Tanatani A., Yamaguchi K., Azumaya I., Fukutomi R., Shudo K., Kagechika H., J. Am. Chem. Soc., 120, 6433-6442 (1998).

11) Yamaguchi K., Matsumura G., Kagechika H., Azumaya I., Ito Y., Itai A., Shudo K., J. Am. Chem. Soc., 113, 5474-5475 (1991).

12) Tanatani A., Kagechika H., Azumaya I., Fukutomi R., Ito Y., Yamaguchi K., Shudo K., Tetrahedron Lett., 38, 4425-4428 (1997).

13) Tanatani A., Azumaya I., Kagechika H., Yuki Gosei Kagaku Kyokai Shi, 58, 556-567 (2000).

14) Yokozawa T., Asai T., Sugi R., Ishigooka S., Hiraoka S., J. Am. Chem. Soc., 122, 83138314 (2000).

15) Kobayashi N., Muranaka A., Yuki Gosei Kagaku Kyokai Shi, 64, 735-743 (2006) .

16) Tanatani A., Yokoyama A., Azumaya I., Takakura Y., Mitsui C., Shiro M., Uchiyama M., Muranaka A., Kobayashi N., Yokozawa, T., J. Am. Chem. Soc., 127, 8553-8561 (2005).

17) Okamoto I., Nabeta M., Hayakawa Y., Morita N., Takeya T., Masu H., Azuamya I., Tamura O., J. Am. Chem. Soc., 129, 18921893 (2007).

18) Tojo Y., Urushibara K., Yamamoto S., Mori H., Masu H., Kudo M., Hirano T., Azumaya I., Kagechika H., Tanatani A., J. Org. Chem., 83, 4606-4617 (2018).

19) Saito S., Toriumi Y., Tomioka N., Itai A., $J$. Org. Chem., 60, 4715-4720 (1995).

20) Mikami K., Tanatani A., Yokoyama A., Yokozawa T., Macromolecules, 42, 3849-3851 (2009).

21) Tanatani A., Hughes T. S., Moore J. S., $A n-$ gew. Chem. Int. Ed., 41, 325-328 (2002) .

22) Garric J., Leger J.-M., Huc I., Chem. Eur. J., 13, 8454-8462 (2007).

23) Urushibara K., Masu H., Mori H., Azumaya I., Hirano T., Kagechika H., Tanatani A., $J$. Org. Chem., 83, 14338-14349 (2018).

24) Jiang H., Léger J.-M., Guionneau P., Huc I., Org. Lett., 6, 2985-2988 (2004).

25) Urushibara K., Ferrand Y., Liu Z., Masu H., Pophristic V., Tanatani A., Huc I., Angew. Chem. Int. Ed., 57, 7888-7892 (2018). 